\author{
(online) $=$ ISSN $2285-3642$ \\ ISSN-L = $2285-3642$ \\ Journal of Economic Development, Environment and People \\ Volume 6, Issue 2, 2017 \\ URL: http://iedep.spiruharet.ro \\ e-mail: office jedep@spiruharet.ro
}

\title{
Banking Systems in Romania and Iceland: Two Different Worlds but Similar Development
}

\author{
Claudia Gabriela Baicu ${ }^{1}$ and Mar Wolfgang Mixa \\ ${ }^{1}$ Spiru Haret University \\ ${ }^{2}$ Reykjavik University
}

\begin{abstract}
The novelty of this article is the comparative analysis of the Romanian and Icelandic banking systems. The study results reveal that despite the fact that Romania and Iceland are two different worlds, there are several similarities between the banking systems of these countries. They include a late development of banking systems, foreigners contributing a great deal to the development of the banking systems in the early stage of evolution. After the Second World War until the 1990s specialized banks operated in both countries. The banking systems of both countries prior to the 1990s were dominated by politics. Liberalization of banking and capital occurred both in Romania and Iceland after 1990; the bank privatization process took place during a similar period (1999-2006, Romania; 1998-2002, Iceland). Before privatization, banks in both countries lacked experience in a new banking "arena". The global financial crisis greatly affected the two banking systems. Despite similarities, the evolution of the two banking systems was also marked by differences, notably the ownership origin of banks after privatization (foreign dominance in Romania; domestic owners in Iceland) and different business models developed by banks in the pre-crisis period.
\end{abstract}

Keywords: Romanian banking system, Icelandic banking system, global financial crisis, Romania, Iceland.

JEL Codes: G21, G28, 011

\section{Introduction}

Starting from the important role that banking systems in the two countries have in financial intermediation, we structure the paper in three sections.

The first section is devoted to geographically and historically landmarks of Romania and Iceland. In the second section, we present the main stages in the development of banking systems in the two countries. In that presentation, we emphasize the differences between before and after 1990. This delimitation takes into account the fact that the Romanian banking and financial system started to develop on a modern base after 1990 and the Icelandic financial system began transforming rapidly during the 1990s.

\footnotetext{
- Corresponding author. Tel.: + 0040723317158.

E-mail address: baicuclaudia70@yahoo.ro.
} 


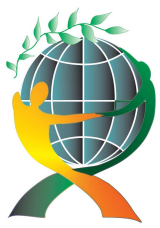

\author{
(online) $=$ ISSN $2285-3642$ \\ ISSN-L = $2285-3642$ \\ Journal of Economic Development, Environment and People \\ Volume 6, Issue 2, 2017 \\ URL: $\underline{\text { http://iedep.spiruharet.ro }}$ \\ e-mail: office jedep@spiruharet.ro
}

Another point of reference in presenting the two banking systems was the global financial crisis, pointing to the banking expansion in the pre-crisis period, the impact of the crisis and further developments.

We compare in the third section the two banking systems. Our discussions highlight the similarities and differences between them.

Over the time, due to the importance of banking system, the specialty literature in both countries devoted great attention to this topic. Concerning the evolution of the Romanian banking system, the periodical publications of the central bank - The National Bank of Romania (NBR) - offer official data on the Romanian banking system. These publications include the Annual Reports and the Financial Stability Reports. The history of the Romanian banking system was presented in many studies like: lonescu (coordinator, 1996); Kiritescu (1997); Mauri, Baicu (2002); Murgescu, Constantinescu (ed., 1960); Pintea, Ruşcanu (1995); Slăvescu (1925). The development of the Romanian banking system in recent years was highly debated in the specialty literature. To this regard the following studies could be mentioned: Zaman, Georgescu (2015); Zaman, Goschina (2015); Zaman (2013); Baicu, State (2012). The Central Bank of Iceland and the Financial Supervisory Authority of Iceland provide valuable information on the evolution of the Icelandic banking system. The specialty literature has paid great attention to the development of the Icelandic banking system in the pre-crisis period and the impact of the global financial crisis. In this regard, the following publications could be mentioned: Sigurjonsson (2010); Special Investigation Commission (2010, 2014); Halldorsson \& Zoega (2010); Bagus \& Howden (2009); Sigurjonsson \& Mixa (2009); Mixa (2016).

\title{
2. Romania and Iceland - Geographically and Historically Landmarks
}

Romania is a country located in the Southeastern part of Central Europe, with an area of 238,391 sq. km (INS, 2015, p. 5). According to the latest census of population and housing in 2011, provided by the National Statistics Institute, on 20 October 2011, Romania had a stable population of 20,121,641 people (INS, 2011). On 1 January 2016, Bucharest - the capital of Romania - had a population of 2,106,144 people (INS, 2016).

After the Second World War, Romania entered under the Soviet Union sphere of influence and the communist regime within the country was established. From the economic point of view, the communist regime involved implementation of the command economy, which included the abolition of private property and introduction of economic planning through development plans approved by the communist leadership.

Due to the limitations of the communist regime that led to the sharp deterioration in living standards, the dictatorial regime of Nicolae Ceausescu, the Romania president at that time, was in 1989 removed.

After 1990, democratic regime was established and the transition from the command economy to the market economy began.

In 2007, Romania joined the European Union (EU). The accession process involved transposing the Community law into the Romanian legislation.

Iceland is located in the northern part of the Atlantic Ocean, with an area of $103,000 \mathrm{sq} . \mathrm{km}$, meaning that Iceland is a bit less than half of the size of Romania. While Romania has a population of around 20 million people, Icelanders only count 340,000 people (Statistics Iceland, not dated). Compared to Romania, Iceland is much more rural. This is somewhat misleading because large parts of Iceland are not habitual since a large part of the country consists of mountains and glaciers. In the capital area of Iceland leave only 


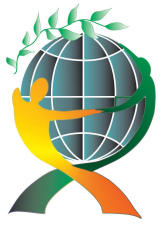

\author{
(online) $=$ ISSN $2285-3642$ \\ ISSN-L = $2285-3642$ \\ Journal of Economic Development, Environment and People \\ Volume 6, Issue 2, 2017 \\ URL: http://iedep.spiruharet.ro \\ e-mail: office jedep@spiruharet.ro
}

approximately 200,000 people, while Romania's capital, Bucharest, inhabits about 10 times the amount of people. Iceland gained full independence from Denmark in 1944. The country is generally considered to be similar to other Nordic countries but still showing elements of American cultural values with a market economy but a strong emphasis on social benefits, mainly poverty alleviation (Olafsson, 2003).

\title{
3. STRUCTURE of the FINANCIAL and BANKING SYSTEM in ROMANIA and ICELAND
}

The evolution of the Romanian banking system has been influenced by a lot of factors where the political one played a decisive role. There are two distinct periods that were different in terms of organization and operation of the financial systems: the communist period and the period after 1990.

The Icelandic financial system experienced a similar development, being prior to 1990s restricted in a politicalized environment, with banks mostly servicing certain groups. It began quickly transforming from the mid-1990s and growing massively during the Manic Millennium Years (Mixa, 2009).

\subsection{The Romanian financial and banking system prior to $\mathbf{1 9 9 0}$}

The first bank that operated on the Romanian territory was Banca Națională a Moldovei (The National Bank of Moldova), founded in 1856 (Ionescu coordinator, 1996, p. 18). The establishment of the public institutions - Casa de Depuneri şi Consemnațiuni (The Deposits and Consignments House) in 1864 and Casa de Economii (The Savings House) in 1880 - marked a major stage for the Romanian banking system (Gusti, 1943, p. 581-589).

The issuing Bank of Romania - The National Bank of Romania (NBR) was established by the Law no. 17/29 of April 1880 (Kiritescu, 1997, p. 304-305). The NBR played an important role in Romanian banking system creation and development.

The number of banks grew rapidly: from 1, in 1874 to 222, in 1918 (Gusti, 1943, p. 561).

The 1929-1933 crises had severe impact on the Romanian banking system. Prior to the crisis the number of banks increased and the banking system developed. However, the lack of maturity of the Romanian banking system and the undercapitalization of many banks caused many problems (Mauri and Baicu, 2002, p. 47-48).

The transition towards the communist regime profoundly affected the Romanian banking system through the administrative measures taken in that era, among which very important were:

- $\quad$ the passage of The National Bank of Romania as a state ownership - January $1^{\text {st }}, 1947$;

- $\quad$ the establishment of the monobank system, involving the accumulating of banking operations within a single institution, which fulfilled both the functions of a central bank and commercial banks. This process involved the liquidation or dissolution of most commercial banks that existed in Romania prior to 1948;

- $\quad$ restriction of foreign bank capital; with only four banks operating with foreign capital or joint capital (Romanian and foreign capital) in Romania (Chemical Bank, Société Générale, Banca FrancoRomână and Frankfurt Bucharest Bank).

Another measure that was taken was the creation of some specialized banks to fund various economic sectors or to attract savings from the population:

- $\quad$ Banca de Investiții (The Investment Bank), specialized in investment finance;

- Banca pentru Agricultură şi Industrie Alimentară (The Bank for Agriculture and Food Industry), specialized in financing the agricultural sector; 


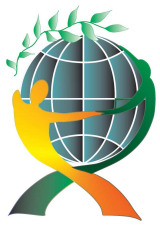

\author{
(online) $=$ ISSN $2285-3642$ \\ ISSN-L = $2285-3642$ \\ Journal of Economic Development, Environment and People \\ Volume 6, Issue 2, 2017 \\ URL: $\underline{\text { http://iedep.spiruharet.ro }}$ \\ e-mail: office jedep@spiruharet.ro
}

- Banca Română de Comerț Exterior (The Romanian Bank for Foreign Trade), specialized in trade finance;

- $\quad$ Casa de Economii şi Consemnațiuni (The Savings House), detained monopoly in terms of savings from the population (Ionescu coordinator, 1996, p. 20-22).

Stock exchange activity in Romania does not have a long tradition. The Bucharest Stock exchange was opened in December 1882, but at the first stage of functioning, the activity was reduced (Popa, 1993, p. 259). During the communist regime, the stock exchange did not operate anymore. The political changes affecting Romania at end-1989 created the premises for capital market development. Therefore, The Bucharest Stock Exchange was re-established in 1995 (Anghelache, 2004, p. 25-29).

\title{
3.2. The Romanian financial system after 1990
}

After 1990, the Romanian banking system has been restructured and modernized. In the first stage of transition, the new legislative framework was adopted. The monobank system was abolished and the twotier banking system was implemented.

As a result, during 1991-1998, the number of banks increased from 8 to 36 banks, of which 27 were Romanian legal entities, and 9 branches of foreign banks (the number of banks increased approximately 7 times). Nevertheless, at end-1998, the Romania's banking system was dominated by four banks with majority state capital (Bancorex, Banca Română de Dezvoltare, Banca Comercială Română, Banca Agricolă) that accounted for 62 percent of total banking assets. In addition, Casa de Economii şi Consemnațiuni (CEC The Savings House), entirely detained by the state, accounted for 9.8 percent of total banking assets (BNR, Rapoarte anuale 1996-2000, p. 297-298).

Despite this progress, the Romanian banking system has faced many problems. Amid the disruptions at economic level that accompanied the transition process, the large state-owned banks lacked the experience and expertise within the new framework. The central bank in a similar manner also lacked experience in the supervision process during the early stages of transition. This led to some state-owned banks experiencing the problem of non-performing loans.

Banca Agricola (The Agriculture Bank) and Bancorex were among the most affected banks. They had sectoral exposures towards enterprises in the energy sector and farming sector, respectively. At end-1998, the non-performing loans in the Romanian banking system accounted for more than 54 percent of total (NBR, Annual Report 1998, p. 78-79).

In this context, the restructuring of state-owned banks began. In 1998, The Bank Asset Recovery Agency was established in order to take over the non-performing loans of state-owned banks to prepare the privatization process (Guvernul României, 1998).

In 1999, Bancorex - the largest state-owned bank - was merged with Banca Comercială Română (The Romanian Commercial Bank). The cost the government bore of the restructuring of the Romanian banking sector accounted for 10 percent of GDP during 1990-2003(NBR, Financial Stability Report 2006, p. 49).

The actions of restructuring state banks and the adoption of necessary legislative framework have laid the groundwork for starting the privatization of state banks, either by establishing new banks or having other banks entering the Romanian banking sector.

The privatization of state owned banks began in 1999. This process has boosted the penetration of foreign capital in the Romanian banking system. Examples include the French bank Société Générale buying the majority stake of Banca Română de Dezvoltare (The Romanian Bank for Development) and Generale 


\author{
(online) $=$ ISSN $2285-3642$ \\ ISSN-L = $2285-3642$ \\ Journal of Economic Development, Environment and People \\ Volume 6, Issue 2, 2017 \\ URL: http://iedep.spiruharet.ro \\ e-mail: office jedep@spiruharet.ro
}

Electric Capital Corporation and the Banco Portugues de Investimento buying the controlling stake in The Banc Post (BNR, Rapoarte anuale 1996-2000, p. 393-394).

Therefore, at end- 2000 foreign-owned banks held 50.88 percent of the domestic markets compared to the state-owned banks that held 46.1 percent (NBR, Annual report 2000, p. 99).

In 2001 the privatization of Banca Agricola followed and the state equity holding was sold to a consortium made up of Raiffeisen Zentralbank Österreich A.G. (93.13 percent) and the Romanian-American Enterprise Fund (5.7 percent) (NBR, Annual Report 2001, p. 80). Banca Comercială Română was privatized and taken over by the Erste Bank (Austria) în 2006.

Currently, the Romanian banking system is characterized by the dominant presence of foreign capital. At end-2015, credit institutions with a majority foreign capital (including branches of foreign credit institutions) detained 90.4 percent of aggregate net assets. Credit institutions with majority state-owned capital hold 8.3 percent of aggregate assets. Regarding the country of origin of foreign capital, the topthree countries are:

- $\quad$ Austria, 33.3 percent of net assets;

- $\quad$ France, 13.5 percent of net assets;

- $\quad$ Greece, 10.6 percent of net assets.

At end-2015, there were 36 credit institutions, thereof 29 credit institutions Romanian legal entities and 7 branches foreign credit institutions. Following the privatization process, only two fully or majority stateowned capital credit institutions were still operating (NBR, Annual Report 2015, p. 93-94).

The private pension funds in Romania are relatively new. They were introduced in 2008. By comparison, the private pension system (the mandatory private pensions) was introduced in Hungary in 1998, in Poland in 1999, in Lithuania in 2004, in the Slovak Republic in 2005 (The World Bank, 2013, p. 4). Currently, the insurance and private pension system are regulated and supervised by the Financial Supervisory Authority. This authority was established to integrate supervision of non-bank financial markets (with exception of non-bank financial institutions) in order to increase the efficiency of the financial supervision (Guvernul României, 2012).

The shadow banking sector in Romania is not well represented compared to some developed countries. Shadow banking sector accounts for $\mathbf{1 5 . 5}$ percent of total financial assets and includes non-banks financial institutions, investment funds and money-market funds (NBR, Financial stability report 2015, p. 105). Both non-banks financial institutions and investment funds are regulated and supervised: non-banks financial institutions are regulated and supervised by the National Bank of Romania and investment funds, by the Financial Supervisory Authority. 


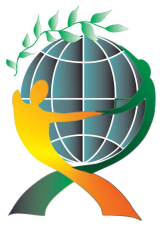

\author{
(online) $=$ ISSN $2285-3642$ \\ ISSN-L = $2285-3642$ \\ Journal of Economic Development, Environment and People \\ Volume 6, Issue 2, 2017 \\ URL: http://iedep.spiruharet.ro \\ e-mail: office jedep@spiruharet.ro
}

\title{
3.3. The impact of the global financial crisis on the Romanian banking system
}

The Romanian banking system was severely affected by the global financial crisis despite the business model adopted by the Romanian banks being the traditional one:

- unlike other banking systems, the balance sheets of the Romanian banks did not contain "toxic" assets;

- the shadow banking in the Romanian system was not well represented;

- securitization was not used in the Romanian banking system;

- the most important liabilities of the Romanian banking system were the traditional deposits from non-bank sector (in 2007, non-bank sector deposits accounted for 52.6 percent of total liabilities see table 1);

- different bonuses in the remuneration system did not play a significant role in the Romanian banking system compared to developed countries (for more details see Baicu and State, 2012).

Besides, after triggering the crisis, unlike other countries, the Romanian state did not allocate funds to capitalize banks.

Despite these differences, in some aspects, the behavior of the Romanian banks in the pre-crisis period was similar to the behavior of banks in other countries. The expansion of the credit activity is one example. In order to improve their profitability, many banks relaxed the credit conditions that profoundly affected the quality of credit portfolios once the crisis hit international markets.

Remuneration based on short-term results was also present in the Romanian banking system with a negative impact on the quality assets on medium and long term, as also strongly noticed after the triggering of the global crisis.

Other characteristic of the Romanian banking system that could be included in the pre-crisis global trends was financing the credit expansion in great part through wholesale market, namely through funding received from parent banks in origin countries. Therefore, foreign liabilities grew from 15.9 percent in 2004 to 31.7 percent in November 2008 (see table 1).

Nevertheless, in a global world, the Romanian banking system could not be immune to the crisis that propagated in Romania latter. The global crisis affected the Romanian banking system in multiple ways and foreign banks played an important role in crisis propagation.

Against the immediate liquidity problem at an international level and the pressure to meet the level of capital adequacy according to the new regulatory framework, parent banks diminished the funding of their subsidiaries in Romania. In this context, foreign liabilities of credit institutions operating in Romania decreased gradually from 31.7 percent of total liabilities in November 2008 (NBR, Financial Stability Report 2009, p. 22) to 15.5 percent of the balance sheet in December 2015 (NBR, Financial Stability Report April 2016 , p. 48), meaning that this percentage went down by half. The diminishing of credit lines from parent banks was offset by the increase of private sector deposits - which were 60.8 percent of bank liabilities in December 2015 (NBR, Financial Stability Report April 2016, p. 48). 


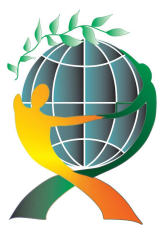

\author{
(online) $=$ ISSN $2285-3642$ \\ ISSN-L = $2285-3642$ \\ Journal of Economic Development, Environment and People \\ Volume 6, Issue 2, 2017 \\ URL: http://iedep.spiruharet.ro \\ e-mail: office jedep@spiruharet.ro
}

Table 1 Liability structure of credit institutions operating in Romania

\begin{tabular}{|c|c|c|c|c|c|c|c|c|c|c|c|}
\hline & 2004 & 2005 & 2006 & 2007 & $\begin{array}{l}\text { Sep. } \\
2008\end{array}$ & $\begin{array}{l}\text { Oct. } \\
2008\end{array}$ & $\begin{array}{l}\text { Nov. } \\
2008\end{array}$ & $\begin{array}{l}\text { Dec. } \\
2008\end{array}$ & $\begin{array}{l}\text { Jan. } \\
2009\end{array}$ & $\begin{array}{l}\text { Feb. } \\
2009\end{array}$ & $\begin{array}{l}\text { Mar. } \\
2009\end{array}$ \\
\hline $\begin{array}{l}\text { Domestic liabilities, } \\
\text { of which: }\end{array}$ & 84.1 & 79.1 & 77.5 & 71.7 & 70.2 & 69.4 & 68.3 & 69,3 & 70,0 & 70.9 & 71.2 \\
\hline $\begin{array}{l}\text { Interbank deposits } \\
\text { Non-bank sector }\end{array}$ & 3.0 & 2.5 & 3.6 & 3.8 & 2.7 & 4.0 & 2.2 & 2.1 & 4.2 & 5.2 & 6,0 \\
\hline $\begin{array}{l}\text { deposits, of which: } \\
\text { - Government sector }\end{array}$ & 64.9 & 61.0 & 58.1 & 52.6 & 49.0 & 46.8 & 47.0 & 47.8 & 46.1 & 46.1 & 45.8 \\
\hline $\begin{array}{l}\text { deposits } \\
\text {-Corporate and }\end{array}$ & 2.6 & 3.5 & 3.1 & 2.9 & 2.9 & 2.9 & 2.9 & 3.1 & 2.8 & 2.9 & 2.8 \\
\hline household deposits & 62.3 & 57.5 & 55.0 & 49.7 & 46.1 & 43,9 & 44.1 & 44.6 & 43.3 & 43.2 & 42.9 \\
\hline Capital and reserves & 11.7 & 12.2 & 11.8 & 9.9 & 10.4 & 10.7 & 11.0 & 10.7 & 10.3 & 10.5 & 10.7 \\
\hline Other liabilities & 4.5 & 3.4 & 4.0 & 5.4 & 8.1 & 7.8 & 8.1 & 8.8 & 9.3 & 9.7 & 8.7 \\
\hline Foreign liabilities & 15.9 & 20.9 & 22.5 & 28.3 & 29.8 & 30.6 & 31.7 & 30.7 & 30.0 & 29.1 & 28.8 \\
\hline
\end{tabular}

A characteristic of Romania is the low level of financial intermediation with the share of bank assets being 56.0 percent of GDP in September 2016 compared to 66.0 percent of GDP in December 2008 (NBR, Financial Stability Report December 2016, p. 53).

Currently, one of the most important vulnerability of the Romanian banking system is the high non-performing loan ratio. According to the NBR Financial Stability Report December 2016 (p. 57-58), the non-performing loan ratio reached 10 percent (September 2016), which is well above the EU average (5.5 percent, June 2016). However, due to the balance sheet clean-up process, the non-performing loan ratio decreased from 22.0 percent, as was in December 2012 (NBR, Financial Stability Report 2013, p. 54). This high level of non-performing loan ratio is a direct consequence of the aggressive and unsustainable lending policy promoted in the pre-crisis period.

Despite the issue of non-performing loans, other prudential indicators have comfortable levels. For example, the Romanian banking system is characterized by high level of capital adequacy indicators (the total capital ratio accounted for 18.8 percent in September 2016 - NBR, Financial Stability Report December 2016, p. 67). In line with the European and international tendency, after the global crisis, the banking regulatory framework has been improved in Romania too.

\title{
3.4. The Icelandic financial system prior to the $\mathbf{1 9 9 0}$
}

The Icelandic banking system was practically non-existent before 1885 when The National Bank of Iceland was established by the government following Iceland's financial independence from Denmark 10 


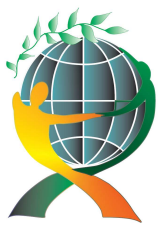

\author{
(online) $=$ ISSN $2285-3642$ \\ ISSN-L = $2285-3642$ \\ Journal of Economic Development, Environment and People \\ Volume 6, Issue 2, 2017 \\ URL: http://iedep.spiruharet.ro \\ e-mail: office jedep@spiruharet.ro
}

years earlier. Savings banks were established during the same period (Jonsson G., 2004). Danish business persons established another bank in 1904 named Islandsbanki (Jonsson A., 2009). The Icelandic government established the Agricultural bank in 1929 (Jonsson G., 2004) and the following year, during the start of the Great Depression, Islandsbanki became bankrupt, with the government establishing from its ruins another bank specifically aiming at servicing another sector, called The Bank of Iceland's Fisheries (Agnarsson, 2004). While serving those specific groups, these moves were viewed as being part of transferring Iceland as a modern and independent nation, which up to that point was almost entirely dependent on agriculture (Finsen \& Skulason, 1938; Jonsson G., 1995).

This trend of servicing special interest groups of borrowers continued during the next decades. Specific interest groups began establishing banks that reflected the name of the groups they mainly served (Johannesson, S. 2004). Examples include The Industrial Bank (1953), The Icelandic Bank of Commerce (1963) and The People's Bank (1971), which was some sort of a union bank (Jonsson A., 2009). All of these three banks merged with the Bank of Fisheries in 1989, with the new bank re-named the old familiar name of Islandsbanki. During the period from 1930 until 1990s, the Icelandic banking environment can be characterized as being restrictive, with capital controls in full effect where political connections and governmental policies, in a similar manner as other Nordic banking systems during most of that era dictated the allocation to industries. The government did not own the smaller but the interest groups that owned them all had strong political ties.

Real interest rates were often negative, meaning that access to money was an asset in itself, with demand constantly higher than supply, meaning that such allocation could easily be described as preferential treatment (Sigurjonsson \& Mixa, 2011; Jonung, 2008; Englund, 1999). Foreign currency restrictions were the norm in Iceland, with special permissions needed for foreign currency to import, invest or even to cover travelling expenses.

\title{
3.5. The Icelandic financial system after $\mathbf{1 9 9 0}$
}

While the Icelandic financial system began transforming rapidly during the 1990s, signs of changes had begun a few years earlier. This included the establishment of a stock exchange in 1985, which was little used the first years of operations, and the liberalization of domestic bank rates in 1985 that became fully liberalized in 1987.

This slow process towards a more market oriented banking system took a major turn in 1994 when Iceland joined the European Economic Area (EEA), opening the doors to the free flow of capital and hence foreign direct investment. Iceland was, in effect, forced to follow the parameters of the EEA agreement (Sigurjonsson \& Mixa, 2011), abolishing currency restrictions and connecting the country's economy in a global manner, leading to restrictions on capital movements being fully abolished the year after. This also opened the door to financial liberalization that had not been in effect since the fall of Islandsbanki (the first version, not the re-named bank) in 1930. These changes aimed at making the Icelandic banking system more efficient, for it was generally accepted that had been bloated and inefficient for many years. Capital movements increased even more and efficiently with the creation of the Interbank Money Market in 1998 followed by the Interbank FX Swap Market in 2002 (Central Bank of Iceland, 2006).

Iceland followed the trend in international banking with added liberalization, meaning that the differences between traditional banking and investment banking became ever less clear. Services related to 


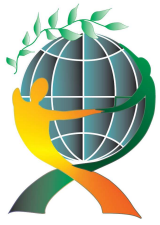

\author{
(online) $=$ ISSN $2285-3642$ \\ ISSN-L = $2285-3642$ \\ Journal of Economic Development, Environment and People \\ Volume 6, Issue 2, 2017
}

URL: http://iedep.spiruharet.ro

e-mail: office jedep@spiruharet.ro

brokerage and investment bank services quickly spread within the industry. Mutual funds, trading for customers and on behalf of the banks became common features of all banks within the 1995-2000 period.

By 2002 the Icelandic banking system was operating mostly as a completely modernized system with the Financial Supervisory Authority though still catching up to the new environment. Simple regulatory functions such as the separation of bankers dealing with the bank's proprietary investments and investments on behalf of their clients had only been enacted 2002 (Financial Supervisory Authority of Iceland, 2002) with further separation between the operation of banks and mutual funds enacted in 2003 (Financial Supervisory Authority of Iceland, 2003). Although some concerns were already being raised regarding the increase in lending (Morgunbladid, 2004; Central Bank of Iceland, 2004), such concerns were (still) shrugged off due to the restrictive lending practices that had been common place for such a long time, causing a pent up demand for such loans.

A privatization process, started in 1992, began to affect the banking system in 1997 and went into full steam 2002 when the government wholly privatized 2 of the 3 main Icelandic major banks. Islandsbanki had risen from the ashes of the combined fragile banks in the early 1990s and in 2000 was merged with an investment bank that had been privatized by the government 2 years earlier. The other two banks, The National Bank of Iceland and The Agricultural Bank were initially partially privatized in 1998, with a large amount of people investing in them. A controlling stake in The National Bank of Iceland was bought by business tycoons that had no prior experience in banking (Sigurjonsson, 2010) while The Agricultural Bank was overtaken by Kaupthing Bank, an investment bank that The Agricultural Bank ironically owned a 50\% stake in until 1996 (Special Investigation Commission, 2014). This development can be seen in table 2.

Table 2 Financial Evolution in Iceland

\begin{tabular}{l|c}
\hline Event & Year \\
\hline Financial Indexation permitted & 1979 \\
Liberalization of domestic bank rates & $1984-1986$ \\
Iceland Stock Exchange established & 1985 \\
Interest Rate Act: Interest rates fully liberalized & 1987 \\
Stepwise liberalization of capital movement begins & 1990 \\
Treasury overdraft facility in the Central Bank closed & $1992-1993$ \\
New foreign exchange regulations marks the beginning of the liberalization of & 1992 \\
cross-border capital movements & 1992 \\
Privatization process launched & 1993 \\
Interbank market for foreign exchange established & 1994 \\
Iceland becomes a founding member of the EEA & 1994 \\
Long term capital movements fully liberalized & 1995 \\
Short term capital movements fully liberalized &
\end{tabular}




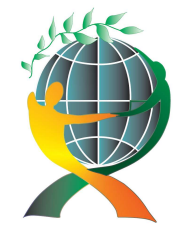

\author{
(online) $=$ ISSN $2285-3642$ \\ ISSN-L = $2285-3642$ \\ Journal of Economic Development, Environment and People \\ Volume 6, Issue 2, 2017
}

URL: http://jedep.spiruharet.ro

e-mail: office jedep@spiruharet.ro

Foreign direct investment liberalized in accordance with EEA agreement

1995

Privatization process of the Icelandic banks begins

1998

Interbank money market

1998

Interbank FX swap market

2001

Privatization of state owned banks completed

2003

Source: Central Bank of Iceland, 2006 and Sigurjónsson \& Mixa, 2011.

Following the privatization of the Icelandic public banks in 2002, they multiplied their size by capitalized money market funding, which included opening branches abroad and acquiring foreign financial institutions in large numbers (Sigurjonsson, 2010). While an explanation of such concerns at that time could have been explained by years of restrictive banking, as can be seen in figure 1, the total assets of the Icelandic banking system continued to increase rapidly, way beyond what a prior restrictive banking environment could explain away.

Figure 1 Total Assets of Iceland's 3 Main Banks and the Savings Banks System

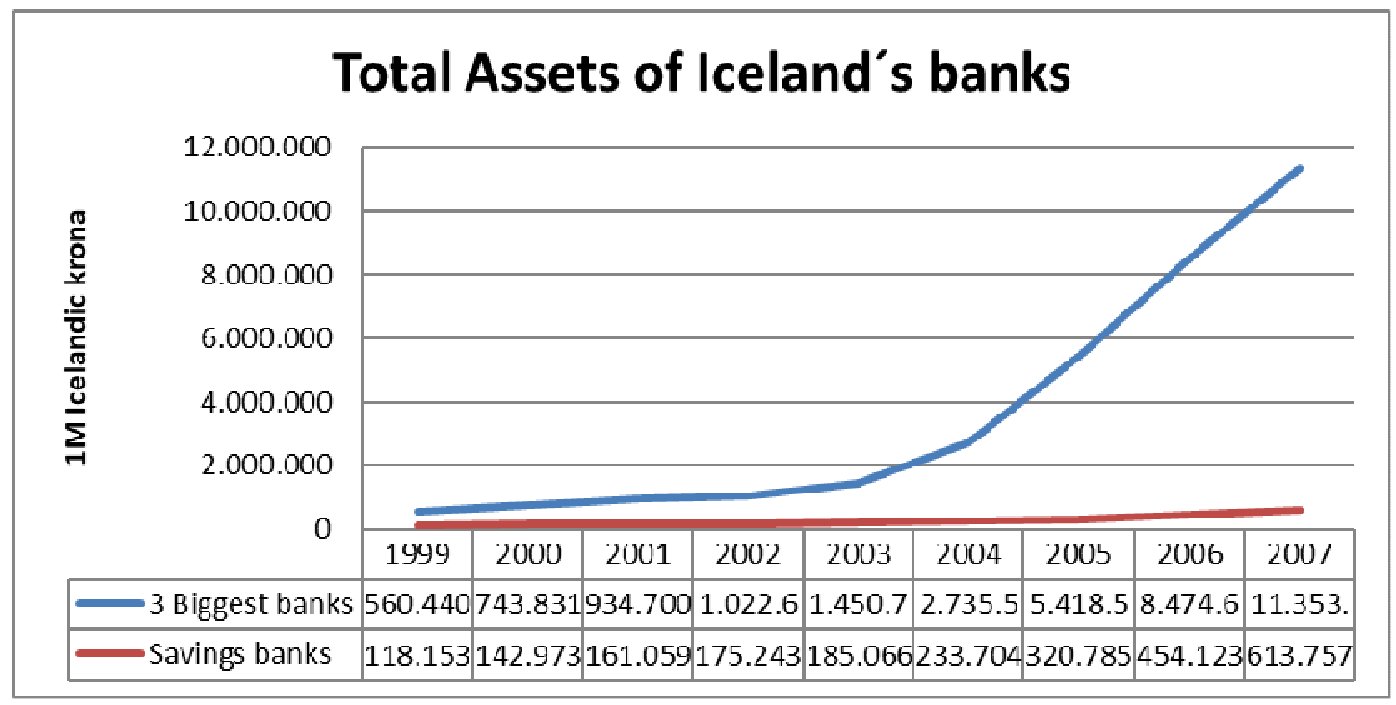

Source: Annual Reports of Iceland's 3 main banks, Kaupthing bank, Islandsbanki and Landsbankinn, Special Investigation Commission (2014) and calculations done by the authors

The combined total assets of Iceland's main three banks were less than Iceland's GDP in 1999. The total assets had gone a long way to three times the GDP in 2003 when concerns of overheating in lending were beginning to be heard. That was, however, just beginning. The combined balance sheets of the banking system, which was approximately the same as the amount of Iceland's gross domestic product (GDP) in a 


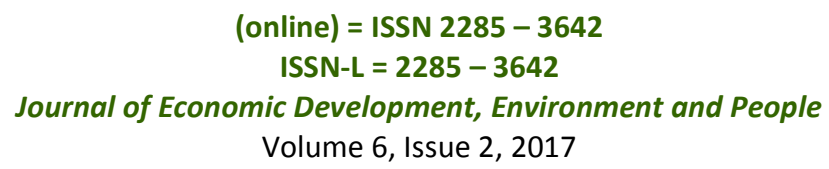

URL: http://iedep.spiruharet.ro

e-mail: office jedep@spiruharet.ro

single year around the 2000, had grown to around 7-8 times that figure in 2007 (Halldorsson \& Zoega, 2010).

By swelling the total assets of the Icelandic banking and putting a more emphasis on investment banking, profits in the friendly investment banking environment in the world were in few places as apparent as in Iceland. Figure 2 shows the increase in equity and profits, using 1 as the base point in 1999 .

Figure 2 The Increase in Equity and Profits of the Icelandic Banking System 1999-2007, using 1999 as a starting point

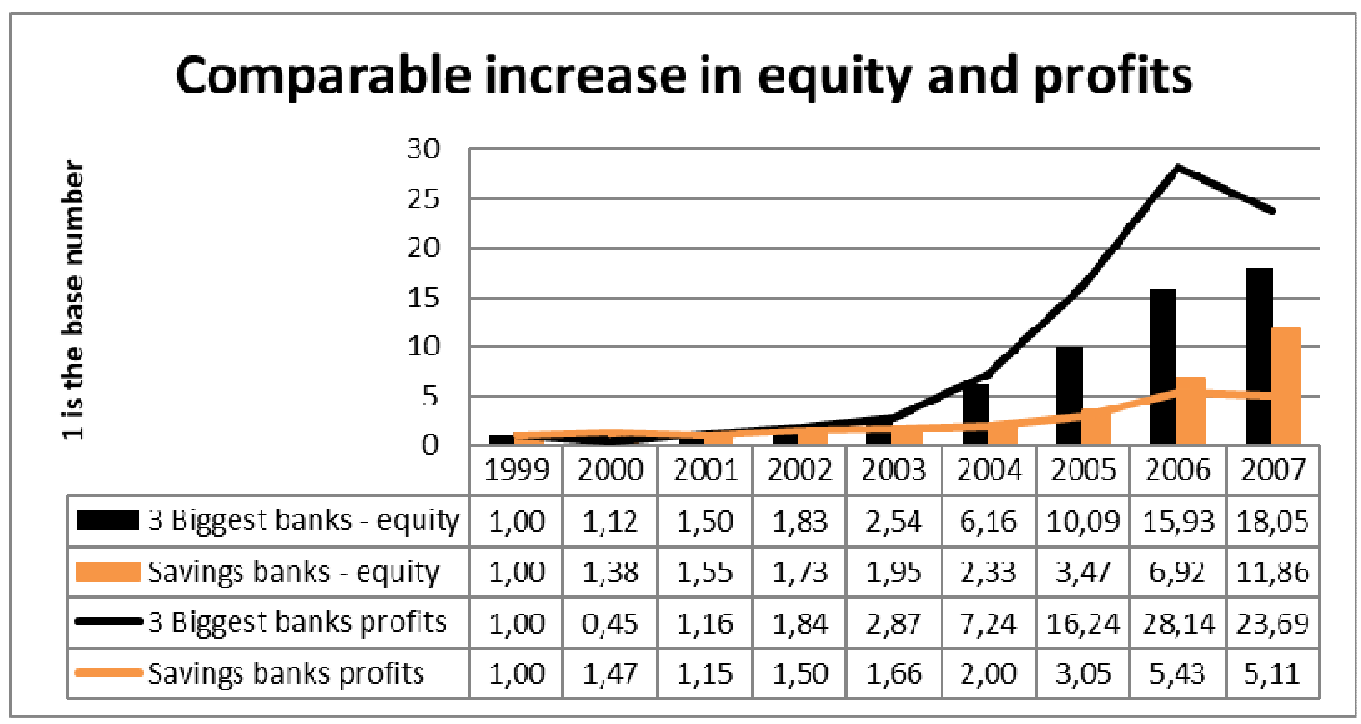

Source: Annual Reports of Iceland's 3 main banks, Kaupthing bank, Islandsbanki and Landsbanki, Special Investigation Commission (2014) and calculations done by the authors

As figure 2 shows, the profits began in earnest swelling and equity increasing in 2003 and onwards. This was not a coincidence. The privatization of the Icelandic banking system was concluded those years. While the overvaluation of technology stocks leading to great losses, events like 9/11 and the bankruptcy of major companies like WorldCom and Enron had had very negative effects on financial markets, the Icelandic banking system rode the tails of fantastic years in the stock market the following years more than practically any banking system in the world.

This rapid growth of the Icelandic banking system opened doors to risky loans and financing methods. The Icelandic banks had financed their obligations on a very short-term basis, for example through newly formed subsidiary Internet banks. Debt, mainly short-term debt maturing in three to five years, had increased a great deal during the years of expansion (Special Investigation Commission, 2010, 3). This was the means to finance the rapid speed of expansion following the privatization of the 3 main banks. Bagus \& 


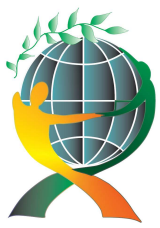

\author{
(online) $=$ ISSN $2285-3642$ \\ ISSN-L = $2285-3642$ \\ Journal of Economic Development, Environment and People \\ Volume 6, Issue 2, 2017 \\ URL: http://iedep.spiruharet.ro \\ e-mail: office jedep@spiruharet.ro
}

Howden (2009) maintain that this made them more vulnerable to the liquidity crisis during the 2007-2009 period, resulting in Iceland's 3 main banks' failure to refinance their short-term debt following a run on deposits in the UK and Netherlands.

The fall of Lehman Brothers in September 2008 demonstrated that a large financial firm could go bankrupt without nation state assistance. With international money markets completely frozen, liquid resources vanished and assets became untradeable. A bank run began on the complete Icelandic financial system. The government took over Glitnir bank's operations on October 6. Due in part to the interconnectedness of the Icelandic banking system, both Landsbanki and Kaupthing bank followed in the following days.

The losses were enormous. The Icelandic economy went into a tailspin with a combination of the Icelandic krona losing half of its value (Central Bank of Iceland database, not dated), the stock market practically losing all of its value and the pension fund system losing around $25 \%$ of its assets (Icelandic Pension Funds Association, 2012). Many Icelanders lost their homes, jobs and security with unemployment reaching levels not seen in decades (Sigurjonsson \& Mixa, 2011). While the Icelandic nation lost a great deal, it could have been worse. The credit losses were unheard of, with foreigners losing what amounted to two times the amount of Iceland's entire real estate value (Mixa, 2011), with the Icelandic banks combined losses only less than Lehman Brothers when it comes to credit default the entire 1920-2008 period (Moodys, 2009).

While those losses were enormous, the Icelandic government has managed to re-build the banking system. New banks were formed with the assets from the old banks transferred to newly established banks. Arion bank was formed with the Icelandic government owning $13 \%$ of the bank, Islandsbanki became wholly owned by the Icelandic government in 2015 following negotiations with creditors (Ministry of Finance and Economic Affairs, 2017b) with Landsbanki also wholly owned by the Icelandic government in 2009.

Laws and regulations have been tightened. A major issue revolves around the "Too Big to Fail" concept, i.e., banks that entail systematic financial risks. During the 2008 financial crisis, it became obvious how intertwined the Icelandic banks were with each other and how their operations affected the Icelandic economy and hence society. With this in mind, the minimum equity ratio for the three big commercial banks rose from $8 \%$ (Financial Supervisory Authority of Iceland, 2014) to 16.5\%; with banks that may pose systematic financial risks having an additional $2 \%$ combined capital buffer compared to other less systematically important banks (Financial Supervisory Authority of Iceland, 2016). This was done to ensure that the Icelandic banking system is more immune towards domino effects during a banking crisis. Icelandic banks have been responding to this scenario. By looking at the ratio of equity against total liabilities, the ratio has been increasing in recent years, although in small degrees.

When one looks at the equity ratio, i.e., the amount of equity compared to total assets, one can see that it is relatively high. While total assets have increased around $14 \%$ during the last five years, the equity 


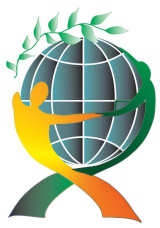

\author{
(online) $=$ ISSN $2285-3642$ \\ ISSN-L = $2285-3642$ \\ Journal of Economic Development, Environment and People \\ Volume 6, Issue 2, 2017 \\ URL: $\underline{\text { http://iedep.spiruharet.ro }}$ \\ e-mail: office jedep@spiruharet.ro
}

of banks has increased $27 \%$ during the same period. Looking at the equity/total assets ratio, the banks are less leveraged now than they used to be shortly after the crisis.

Table 3 The Combined, Assets, Equity and Equity/Assets ratios of the Three Main Icelandic Banks

\begin{tabular}{|rccccc|}
\hline Icelandic krona M & $\mathbf{2 0 1 6}$ & $\mathbf{2 0 1 5}$ & $\mathbf{2 0 1 4}$ & $\mathbf{2 0 1 3}$ & $\mathbf{2 0 1 2}$ \\
Total Equity & 641.556 & 668.658 & 598.490 & 553.577 & 503.726 \\
Total Assets & 3.194 .711 & 3.175 .427 & 2.943 .398 & 2.956 .425 & 2.808 .862 \\
Equity/Assets ratio & $20 \%$ & $21 \%$ & $20 \%$ & $19 \%$ & $18 \%$ \\
\hline
\end{tabular}

Source: 2016 Annual Reports of Arion Bank, Landsbanki and Islandsbanki (2017)

This may be surprising since the stableness of the Icelandic banking system has increased a great deal. While the ratio of non performing loans was high following the crash, it has for example gone from $31.4 \%$ at Landsbanki in 2012 down to only 2.4\% in 2016 (Landsbanki, 2017). The same bank, actually the whole Icelandic banking system, had for a short while a rating of AAA in 2007, but even at that time was controversial (Globe and Mail, 2007). Following the crash, Landsbanki received a junk-bond rating of BB+, which could be considered being a speculative investment grade, but has now followed in the footsteps of the Icelandic government by having better investment ratings, which is today up to BBB, which is an investment grade rating.

Iceland's GDP in 2016 was approximately 2,400,000M Icelandic krona (Statistics Iceland, not dated) which means that the total assets of the Icelandic banks compared to Iceland's GDP is slightly higher than 1.2 fold. The main systematic risk for the Icelandic government has today more relevance due to its ownership in the banks, which price-to-book value today is close to $500,000 \mathrm{M}$ Icelandic krona, or over $20 \%$ of Iceland's GDP (Ministry of Finance and Economic Affairs, 2017b; Landsbanki, 2017; Arion bank, 2017; Islandsbanki, 2017; Statistics Iceland, not dated \& authors' calculations). If the Icelandic banking system would suffer another crisis, there would be a double blow, with both an economic crisis and taxpayers at the same time, possibly having to finance a crumbling banking system.

There is thus a great deal of talk of making the Icelandic banking system smaller, possibly selling part of Iceland's ownership back to private investors with the current government looking into possibilities of selling its stake in the Icelandic banks. Doing that would, however, take many years using merely the domestic market. Also, many people oppose such a sale, pointing out how badly the former privatization ended. There is also much talk about separating the investment side of banking and commercial banking. It has actually become an annual theme in Parliament to introduce legislation to separate such units, with many pointing out the inherent dangers of allowing banks to participate in investment banking backed with government assistance in the form of for example deposit insurance (Mixa, 2015). It does not mean that banking can be safe simply by concentrating on commercial banking (Admati \& Hellwig, 2013) but the risk level of banking does without doubt increase once banks are allowed into the investment-banking arena. 


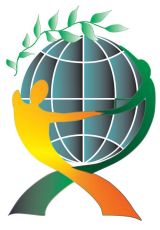

\author{
(online) $=$ ISSN $2285-3642$ \\ ISSN-L = $2285-3642$ \\ Journal of Economic Development, Environment and People \\ Volume 6, Issue 2, 2017 \\ URL: $\underline{\text { http://iedep.spiruharet.ro }}$ \\ e-mail: office jedep@spiruharet.ro
}

\title{
4. Discussions on Comparative Study of the Romanian and Icelandic Banking Systems
}

\subsection{Similarities between the two banking systems}

If we are looking superficial, Romania and Iceland might seem to have witnessed a development of very different banking systems. A closer inspection, however, reveals many similarities.

Both banking systems were characterized by late development. In Romania, the bank that issues currency - The National Bank of Romania - was founded in 1880, only five years before The National Bank Iceland, founded in 1885. Also, the savings banks were established in the two countries in about the same period of time. Both in Romania and Iceland, foreigners have contributed to the creation and development of banking systems. One can mention Danish traders in Iceland or French and German capital in Romania (see Murgescu, Constantinescu ed., 1960) and also those Icelandic banks were to a great extent funded through European banks during the 1999-2008 period.

Prior to the 1990s, both countries had banking systems dominated by politics. In Romania, the Communist party controlled the system centrally. In Iceland, the political ties concealed to some extent that while different banks existed, those banks were mostly tools for pressure groups to gain access to money, which often was to some extent free due to negative interest rates. It can thus be said that both countries only started during the 1990s to develop banking systems that can be described in varying portions as modernized.

A common feature of both banking systems prior to the 1990s was the presence of specialized banks. The names of these banks reflected the sector they served. There were the following specialized banks in Romania:

- Banca de Investiții (The Investment Bank);

- Banca pentru Agricultură şi Industria Alimentară (The Bank for Agriculture and Food Industry);

- Banca Română de Comerț Exterior (The Romanian Bank for Foreign Trade);

- Casa de Economii şi Consemnațiuni (The Savings House).

The specialized banks that operated in Iceland:

- The Industrial Bank;

- The Icelandic Bank of Commerce;

- The Bank of Fisheries.

As one can notice, the names of these specialized banks in both countries were similar, the sectors served by specialize banks being the same (commerce, industry, agriculture).

In Romania, the liberalization of banking and capital began after 1990. There were few banks at the beginning of the transition process towards the market economy. In a similar fashion, the liberalization of capital began for real in Iceland after 1995.

The accession to the European Union, respectively the European Economic Area, played an important role for internationalization of both Romania and Iceland. The Agreement for Romania's Association to the EU was signed in 1993 and the official application for EU membership was presented in 1995. Romania joined the EU in 2007 (Ministerul Afacerilor Externe, Chronology of Romania-EU relations, available at https://www.mae.ro/sites/default/files/file/userfiles/file/pdf/chronology_romania_ue.pdf). To this end, the Romanian legislation has been aligned with the EU legislation by adopting the acquis communautaire. Iceland joined the European Economic Area in 1995. 


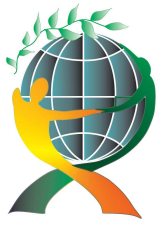

\author{
(online) $=$ ISSN $2285-3642$ \\ ISSN-L = $2285-3642$ \\ Journal of Economic Development, Environment and People \\ Volume 6, Issue 2, 2017 \\ URL: $\underline{\text { http://iedep.spiruharet.ro }}$ \\ e-mail: office jedep@spiruharet.ro
}

Other similarities regarding the privatization process of banking system. Until privatization process began, there were big state Romanian banks without experience and expertise in "new" banking. The first state owned bank was privatized in 1999. Subsequently, the privatization of Banca Comercială Română in 2006 almost completed the privatization process of the Romanian banking system. In Iceland, the bank privatization was realized during 1998-2002. Like the banks in Romania, prior to the privatization process, Icelandic banks had also almost no experience and definitely no knowledge to handle any financial crisis following such rapid expansion.

In the pre-crisis period, both banking systems expanded activity. The expansion of credit activity in both countries occurred after periods of restrictive banking. The global financial crisis greatly affected both banking systems, even if the business model developed by banks in the two countries were different. Nevertheless, during the pre-crisis period, banks in both countries expanded rapidly that yielded short-term profits without taking into considerations the impact on long term situations.

The global financial crisis greatly affected the two banking systems and consequently both countries have taken measures to improve the banking regulatory framework, in line with the regulatory developments at the international level.

\title{
4.2. Differences between the two banking systems in recent years
}

In the pre-crisis period, the Romanian banks developed the traditional business model. The balance sheets of the Romanian banks did not contain "toxic" assets. Securitization was not used and the shadow banking system was not well represented. After the crisis, the Romanian state did not allocate funds to capitalize banks. On the other hand, in Iceland investment banking expanded rapidly within the banks.

Following the privatization process, the inflow of money for the Romanian banking system came almost entirely from abroad but the banking system in Iceland was to the most extent financed with domestic ownership that relied on a great degree on foreign loans. ${ }^{1}$

This had positive effects on the Romanian banking system in regards to experience in banking and increase competition. There is, however, a downside. Foreign owners of the banks have been reluctant to write off bad loans or face in any meaningful way the non performing loans, which are still so high. Besides, a potential disadvantage of a massive foreign capital contribution in a banking system is the possibility to withdraw rapidly from the local market, with negative effects on the financial system and national economy. In this respect, very important to prevent the withdrawal in disordered manner of cross-border banks groups from both Romania and other countries in Central and Eastern Europe was the Vienna initiative launched in 2009 (see ECBI, Vienna Initiative 1.0 - Overview, available at http://viennainitiative.com/vienna-initiative-part-1/overview/).

Apart the uncertainty related to ceasing operating in Romania, Zaman (2013) underlines the fact that the subsidiaries of foreign banks in Romania pursued firstly the parent-banks interests and then the interests of the Romanian economy.

While the Icelandic government was (rightly) criticized for its reluctance in having foreigners invest in its banking system, meaning that instead they were financed more by foreign creditors, it was easier for the

\footnotetext{
${ }^{1}$ The financing is beyond of this paper but much of the financing of the Icelandic banking system appears to have been through investment schemes in which money was basically printed by banks and some of their best business partners.
} 


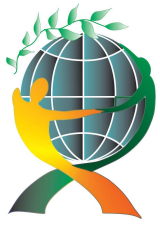

\author{
(online) $=$ ISSN $2285-3642$ \\ ISSN-L = $2285-3642$ \\ Journal of Economic Development, Environment and People \\ Volume 6, Issue 2, 2017 \\ URL: http://jedep.spiruharet.ro \\ e-mail: office jedep@spiruharet.ro
}

Icelandic government to take over the operations of those banks, with foreign creditors picking up most of the losses during the financial crisis. This has enabled the Icelandic banking system to work with creditors in re-scheduling their debt payment plans and, as the example of Landsbanki shows, the non performing loans have gone down to very low levels. ${ }^{2}$

Due to the limited possibilities to develop at an internal level (as we mentioned, Icelanders only count 340,000 people) and eager to generate profits, the Icelandic banks choose to expand oversee and opened offices abroad. Instead, in Romania, foreign banks opened subsidiaries and branches to exploit the growth potential and lack of experience of this market with about 20 million people.

Following a similar discussion regarding the source of money, the ownership nationality shows that problems can emerge regarding agency issues. In Iceland, the domestic owners of banks were accused of various sorts of crony capitalism (Special Investigation Commission, 2010). Such practices utilized, for example, nationalistic themes to have the Icelandic nation accept the risky behavior of the banks' expansion and their rapid growth, which had to entail some risks (Loftsdottir \& Mixa, 2014). While many deemed such behavior as reckless and even stupid, the (domestic) owners of those banks might have had an incentive to take those risks because they did pocket (very) large bonuses while the going was good (Mixa, 2016). While such ownership contributed to the reckless behavior, it also enabled the Icelandic government to tackle the situation much better. After agreements with foreign creditors in 2015, it has even been suggested that the financial (not emotional) damaged from the 2008 crisis by the government has been retrieved (Jonsson \& Sigurgeirsson, 2016).

This was the reverse situation in Romania. While foreign owners were maybe more prudent in their practices, their investments in Romania have been kept to a minimum and the government has limited powers to re-store the banking system in a manner that it begins lending again and thus bringing the Romanian economic growth back on a path of economic growth.

Therefore, due to the vulnerabilities the subsidiaries of foreign banks pose to the Romanian economy, especially in the crisis period, Zaman (2013) considers that a priority of Romania is the development of a banking system with domestic capital to finance the national economy in a sustainable way.

\title{
5. Conclusions
}

The comparative analysis of the Romanian and Icelandic banking systems reveals, surprisingly, a multitude of similarities in terms of historical evolution, despite the fact that between the two countries were big differences from many points of view - economic, political or social. Even geographically, the two countries are located at great distance, with large differences regarding the number of inhabitants.

However, both banking systems began to develop relatively late in the second half of the nineteenth century, with foreign capital playing an important role. The crisis of 1929-1933 affected both banking systems.

After the Second World War, Romania came under Soviet influence and the monobank system was implemented. Even though Iceland did not have the same political evolution, the Icelandic banking system was until the 1990s subject to restrictive controls, with the political factor also playing an important role.

\footnotetext{
${ }^{2}$ The tourist industry boom in Iceland that began in 2010 has also had a great effect in assisting people finding new jobs, making Iceland's GDP growth among the highest in the world in recent years.
} 


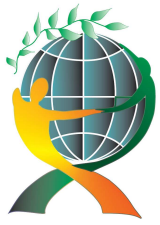

\author{
(online) $=$ ISSN $2285-3642$ \\ ISSN-L = $2285-3642$ \\ Journal of Economic Development, Environment and People \\ Volume 6, Issue 2, 2017 \\ URL: http://iedep.spiruharet.ro \\ e-mail: office jedep@spiruharet.ro
}

After 1990, both banking systems began the process liberalization. Romania's accession to the EU and Iceland's accession to the EEA have been key moments in the development of the two banking systems.

In the late 1990s and early 2000s, the two banking systems were subjected to the privatization process. A notable difference between the two banking systems is the buyers' country of origin for the privatized banks. Foreign capital dominates the Romanian banking system, while in Iceland foreign capital financed the rapid growth to a large degree but the ownership was mostly domestic.

In the pre-crisis period, both banking systems expanded activity. The global financial crisis greatly impacted both banking system, despite the business models developed by banks in the two countries were different.

\title{
6. Acknowledgements
}

The starting point of this paper was the study visit to Reykjavik University performed with financial support received under the EEA Scholarship Programme - R015. The content of this publication is the exclusive responsibility of the authors and the Programme operator; the Ministry of European Funds and the Financial Mechanism Office are not responsible for how the content of information will be used.

More details on the EEA grants for Higher Education: http://eeagrants.org and www.see-burse.ro.

\section{References}

[1] Admati, A. \& Hellwig, M., 2013. The bankers' new clothes: What's wrong with banking and what to do about it. Princeton University Press, Oxfordshire, 46-59.

[2] Agnarsson, S., 2004. Fjármagnið og útgerđin. Í Eggert Pór Bernharđsson (Ritstjóri), Rætur Íslandsbanka 100 ára fjármálasaga, Reykjavík: Íslandsbanki, 95-132.

[3] Anghelache, G., 2004. Piata de capital. Bucharest: Editura Economică.

[4] Arion bank, 2017. Annual Report 2016.

[5] Bagus, P. \& Howden, J.D., 2009. Iceland's banking crisis: The meltdown of an interventionist financial system. Available at Ludwig von Mises Institute website http://mises.org./story/3499 accessed 26 May 2017.

[6] Baicu, C. G. \& State, O., 2012. Banking models under the impact of the post-crisis organizational changes apt to confer sustainable financial stability - Romanian experience. Amfiteatru Economic, Vol. XIV, N. 32 (June).

[7] Bibler, J., 2010. Hversu mikið var fall íslensku bankanna á heimsmælikvarða? [How extensive was the fall of the Icelandic banks internationally?]. Available at http://fme.is/?PagelD=14\&NewsID=521.

[8] BNR (Banca Nationala a Romaniei), Rapoarte anuale 1996-2000.

[9] Central Bank of Iceland, 2004. Ræđa formanns bankastjórnar Seđlabanka Íslands 23. mars, 2004. Available at http://www.sedlabanki.is/uploads/files/\%C3\%81varp\%20BIG\%2023.3.04.pdf accessed 5 June 2017.

[10] Central Bank of Iceland, 2006. The economy of Iceland. Available at http://www.sedlabanki.is/lisalib/getfile.aspx?itemid=4689 accessed 28 December 2008.

[11] Central Bank of Iceland database, not dated.

[12] ECBI, Vienna Initiative 1.0 - Overview. Available at http://vienna-initiative.com/vienna-initiative-part-1/overview/ accessed 27 May 2017. 


\author{
(online) $=$ ISSN $2285-3642$ \\ ISSN-L = $2285-3642$ \\ Journal of Economic Development, Environment and People \\ Volume 6, Issue 2, 2017 \\ URL: http://iedep.spiruharet.ro \\ e-mail: office jedep@spiruharet.ro
}

[13] Englund, P., 1999. The Swedish banking crisis: Roots and consequences. Oxford Review of Economic Policy, 15(3), 80-97.

[14] Financial Supervisory Authority of Iceland, 2002. Leiðbeinandi tilmæli um innra eftirlit og áhættustýringu hjá fjármálafyrirtækjum nr. 1/2002. Available at http://www.fme.is/log-og-tilmaeli/leidbeinandi-tilmaeli/nr/908 accessed 7 June 2017.

[15] Financial Supervisory Authority of Iceland, 2003. Leiðbeinandi tilmæli um aðskilnað reksturs og vörslu og óhæði rekstrarfélaga verđbréfasjóða skv. 15. gr. laga nr. 30/2003, um verðbréfasjóđi og fjárfestingarsjóđi. nr. 5/2003. Available at http://www.fme.is/log-og-tilmaeli/leidbeinandi-tilmaeli/nr/930 accessed 7 June 2017.

[16] Financial Supervisory Authority of Iceland, 2014. Nýjar eiginfjárreglur á grunni CRDIV/CRR. Available at https://www.fme.is/media/frettir/Nyjar-eiginfjarreglur-1.pdf accessed 28 May 2017.

[17] Financial Supervisory Authority of Iceland, 2016. Ákvörđun Fjármálaeftirlitsins um álagningu eiginfjárauka. Available at http://www.fme.is/media/akvardanir/Akvordun-FME-um-alagningu-eiginfjarauka.pdf accessed 28 May 2017.

[18] Finsen and Skulason, 1938. Nutidens Island I tekst og billeder. I anledning af tyveaarsdagen for Islands selvstændighed. Fálkinn, Reykjavík.

[19] Globe and Mail, 2007. A Moody's new take on bank rating has markets crying foul. Available at https://www.theglobeandmail.com/report-on-business/moodys-new-take-on-bank-ratings-has-markets-cryingfoul/article721892/ access 28 May 2017.

[20] Gusti, P.D., 1943. Enciclopedia Romaniei, vol. IV. Bucharest: Imprimeria Nationala.

[21] Guvernul Romaniei, 2012. Ordonanta de urgenta nr. 93/2012 privind infiintarea, organizarea si functionarea Autoritatii de Supraveghere Financiara. Monitorul Oficial, Partea I nr. 874 din 21/12/2012.

[22] Guvernul Romaniei, 1998. Ordonanta de urgenta nr. 51/15 decembrie 1998. Monitorul Oficial, Partea I nr. 482 $\operatorname{din} 15 / 12 / 1998$.

[23] Halldorsson, O. \& Zoega, G., 2010. Iceland's Financial Crisis in an International Perspective. Institute of Economic Studies Working Paper Series. University of Iceland. Reykjavik. Available at http://hhi.hi.is/sites/hhi.hi.is/files/Wseries/2010/WP1002.pdf accessed 8 July 2014.

[24] Icelandic Pension Funds Association, 2012. Úttekt á fjárfestingarstefnu, ákvarđanatöku og lagalegu umhverfi

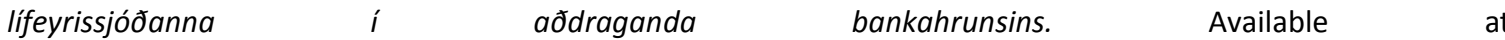
https://rafhladan.is/bitstream/handle/10802/7310/Slides.pdf?sequence=5 accessed June 142017.

[25] INS (Institutul National de Statistica), 2016. Populatia Romaniei pe localitati (January).

[26] INS (Institutul National de Statistica), 2015. Romania in cifre.

[27] INS (Institutul National de Statistica), 2011. Rezultate definitive ale Recensamantului Populatiei şi al Locuintelor 2011 (caracteristici demografice ale populatiei). Available at http://www.recensamantromania.ro/wpcontent/uploads/2013/07/REZULTATE-DEFINITIVE-RPL_2011.pdf) accessed 10 January 2017.

[28] Ionescu, L. (coordinator), 1996. Bancile si operatiunile bancare. Bucharest: Editura Economica, Institutul Bancar Roman.

[29] Islandsbanki, 1999-2007 \& 2017. Annual Reports dated the years 2000-2008 and 2016 but published the year after. 


\author{
(online) $=$ ISSN $2285-3642$ \\ ISSN-L = $2285-3642$ \\ Journal of Economic Development, Environment and People \\ Volume 6, Issue 2, 2017 \\ URL: http://iedep.spiruharet.ro \\ e-mail: office jedep@spiruharet.ro
}

[30] Johannesson, S., 2004. Frelsi á fjármagnsmarkađi eftir 1980. Eggert pór Bernharđsson (editor), Rætur Íslandsbanka 100 ára fjármálasaga. Reykjavík: Íslandsbanki, 185-211.

[31] Jonsson, A., 2009. Why Iceland? New York: McGraw Hill.

[32] Jonsson, A. \& Sigurgeirsson, H., 2016. Kostnaður og endurheimtur ríkissjóđs af falli bankanna. Ministry of Finance and Economic Affairs, Reykjavik. Available at https://www.fjarmalaraduneyti.is/media/frettatengt2016/Kostnadur-og-endurheimturri\%CC\%81kissjo\%CC\%81ds-af-falli-bankanna-skyrsla.pdf accessed 20 May 2017.

[33] Jonsson, G., 1995. Pjóđernisstefna, hagpróun og sjálfstæđisbarátta. Skírnir 169(vor):65-93.

[34] Jonsson, G., 2004. „Myndun fjármálakerfis á Íslandi“, Rætur Íslandsbanka. 100 ára fjármálasaga. Ritstjóri Eggert pór Bernharđsson. Íslandsbanki (Reykjavík 2004), 9-54.

[35] Jonung, L., 2008. Lessons from financial liberalization in Scandinavia. Comparative Economic Studies, 50, $564-598$.

[36] Kaupthing bank, 2002-2007. Annual Reports.

[37] Kiritescu, C., 1997. Sistemul banesc al leului si precursorii lui (vol. I-III). Bucharest: Editura Enciclopedica.

[38] Landsbanki, 2002-2007 \& 2017. Annual Reports dated the years 2003-2008 and 2016 but published the year after.

[39] Loftsdottir, K. \& Mixa, M.W., 2014. Bankar í ljóma pjóđernishyggju. Skírnir, vorhefti.

[40] Mauri, A. \& Baicu, C. G., 2002. Storia della banca in Romania - Parte Prima. Working Paper n. 18. Dipartimento di Economia Politica e Aziendale, Università degli Studi di Milano (luglio).

[41] Ministerul Afacerilor Externe. Chronology of Romania-EU relations. Available at https://www.mae.ro/sites/default/files/file/userfiles/file/pdf/chronology_romania_ue.pdf accessed 27 May 2017.

[42] Ministry of Finance and Economic Affairs, 2017a. Samantekt um skuldir og vaxtagjöld ríkissjóđs. Available at https://www.fjarmalaraduneyti.is/frettir/samantekt-um-skuldir-og-vaxtagjold-rikissjods accessed 24 May 2017.

[43] Ministry of Finance and Economic Affairs, 2017b. Drög að eigendastefnu fyrir fjármálafyrirtæki birt til umsagnar. Available at https://www.fjarmalaraduneyti.is/frettir/drog-ad-eigandastefnu-fyrir-fjarmalafyrirtaeki-birt-tilumsagnar accessed 24 May 2017.

[44] Mixa, M. W., 2009. Once in khaki suits - Socioeconomically Features of the Icelandic Collapse. Ingjaldur Hannibalsson (Ed.), Rannsóknir í Félagsvísindum X, 435-447. Reykjavík: Félagsvísindastofnun Háskóla Ísland.

[45] Mixa, M. W., 2011. Hrun, íbúđarhúsnæđi og Facebook [Crash, private property and facebook]. Available at https://www.slideshare.net/marmixa/20110126-hrun-ibudarhusnaedi-og-facebook accessed May 232017.

[46] Mixa, M.W., 2015. Ađskilnaður banka - núna er rétti tíminn. Available at http://www.mbl.is/vidskipti/pistlar/marmixa/2159988/ accessed May 222017.

[47] Mixa, M.W., 2016. The Icelandic bubble and beyond: Investment lessons from history and cultural effects. Thesis for the degree of doctor of finance. Reykjavik University, Reykjavik.

[48] Moody's, 2009. Corporate Default and Recovery Rates, 1920-2008, 8-19. Available at https://www.moodys.com/sites/products/DefaultResearch/2007400000578875.pdf accessed 22 May 2017. 


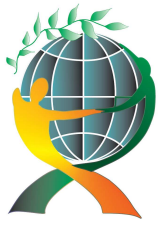

\author{
(online) $=$ ISSN $2285-3642$ \\ ISSN-L = $2285-3642$ \\ Journal of Economic Development, Environment and People \\ Volume 6, Issue 2, 2017 \\ URL: http://iedep.spiruharet.ro \\ e-mail: office jedep@spiruharet.ro
}

[49] Morgunbladid, 2004. "Viđvörun til allra bankanna", 24 March 2004. Available at http://mbl.is/greinasafn/grein/788668/ accessed 24 May 2017.

[50] Murgescu, C., Constantinescu, N.N. (ed.), 1960. Contributii la istoria capitalului strain in Romania: de la sfirsitul primului razboi mondial pina la iesirea din criza economica din 1929-1933. Bucharest: Editura Academiei Republicii Populare Romane.

[51] NBR (National Bank of Romania), Dec. 2016, April 2016, 2015, 2013, 2009 and 2006. Financial Stability Report.

[52] NBR (National Bank of Romania), 2015, 2001, 2000 and 1998. Annual Report.

[53] Olafsson, S., 2003. The identity of Icelanders: Scandinavian or American? Scandinavian Review, 91(1). Retrieved from https://borg.hi.is/IcelandID.pdf.

[54] Pintea, A., Ruscanu, G., 1995. Bancile in economia romaneasca 1774-1995. Bucharest: Editura Economica.

[55] Popa, I., 1993. Bursa, vol. I. Bucharest: Editura Adevarul S.A.

[56] Sigurjonsson, T.O., 2010. Privatization and Deregulation: A Chronology of Events. In Documents on the Asset Price bubble in Iceland, R. Aliber (Ed). Hampshire: Palgrave.

[57] Sigurjonsson, T.O. \& Mixa, M.W., 2011. Learning from the "worst behaved": Iceland's financial crisis and the Nordic comparison. Thunderbird International Business Review, 53(2), 209-223.

[58] Slavescu, V., 1925. Istoricul Bancii Nationale a Romaniei:1880 - 1924. Bucharest: Cultura Nationala.

[59] Special Investigation Commission, 2010. Skýrsla rannsóknarnefndar Alpingis [Report of the Special Investigation Commission regarding the events and causes leading to the fall of the Icelandic banks]. Available at http://sic.althingi.is/ accessed 22 May 2017.

[60] Special Investigation Commission, 2014. Skýrsla rannsóknarnefndar Alpingis um ađdraganda og orsökum, erfiðleika og falls sparisjóðanna [Report of the Special Investigation Commission regarding the events and causes leading to the fall of the Icelandic savings banks system]. Available at https://www.rna.is/media/skjol/RNAsp_Bindi2_K6-10.pdf accessed 22 May 2017.

[61] Statistics Iceland, not dated. Retrieved from the database, accessed 24.5 .2017 at http://px.hagstofa.is/pxen/pxweb/en/Ibuar/Ibuar_mannfjoldi_1_yfirlit_yfirlit_mannfjolda/MAN00000.px/tab le/tableViewLayout1/?rxid=e0e181ea-08c9-40f7-8ffe-593d5c6ed648.

[62] The World Bank, 2013. Reversal and Reduction, Resolution and Reform: Lessons from the Financial Crisis in Europe and Central Asia to Improve Outcomes from Mandatory Private Pensions (May).

[63] Zaman, Gh., Georgescu, G., 2015. Challenges of bank lending in Romania on short, medium and long term. Procedia Economics and Finance 22. Elsevier 88-94.

[64] Zaman, Gh., Goschina, Z., 2015. Romania's sustainable development requirement from the viewpoint of regional economic bank's crediting. Procedia Economics and Finance 32. Elsevier, 125-130.

[65] Zaman, Gh., 2013. Aspects and Trends of crediting the Romanian Economy in Lei and Foreign Currency During the Pre- and Post-Accession Periods. Romanian Journal of Economics, Volume 36, Issue 1(45) (June). 